\title{
O poder atômico do miniconto: análise de narrativas ultracurtas divulgadas em concursos na internet
}

\author{
Elizete RODRIGUES ${ }^{2}$ \\ Vanderlei de SOUZA ${ }^{3}$ \\ Marlene de Almeida Augusto de SOUZA ${ }^{4}$
}

\begin{abstract}
O bom senso, nos tempos vindouros, possivelmente insistirá em medir uma obra de arte antes pelo objetivo que atinge, pela impressão que provoca, que pelo tempo que levou para atingir esse objetivo, ou pela extensão do "esforço sustentado" necessário para produzir essa impressão. (Edgar Allan Poe) ${ }^{5}$
\end{abstract}

Resumo: O presente estudo buscou contribuir para a valorização do gênero miniconto a partir da compreensão teórica de sua natureza e da seleção e análise de obras divulgadas por concursos literários na Internet. Para esse intento utilizamos, principalmente, os trabalhos dos brasileiros Capaverde (2004), Gonzaga (2007), Spalding (2008) e Sanfelice (2009), além de conceitos de expoentes clássicos da teoria do conto, como a unidade de efeito de Poe, a abertura epifânica de Cortázar, a teoria do iceberg de Hemingway e a teoria de que um conto sempre conta duas histórias, atribuída a Borges e desenvolvida por Piglia. Como resultados, pudemos constatar que existem excelentes exemplares do gênero a circular quase que incógnitos pela rede de computadores e que sua análise reafirma o potencial de significação que trazem em seu pequeno corpo, uma vez acionada uma leitura ativa eficiente. Concluímos que, pelo seu caráter compacto e pela sua grande capacidade de produzir interpretações, o gênero se presta para a formação do leitor crítico. Ao final, recomendamos que a pesquisa educacional na área de leitura volte sua atenção para esse filão ainda por explorar.

Palavras-chave: Conto. Minificção. Miniconto.Teoria Literária.

Abstract: The current study seeks to contribute to value the micro-fiction genre through its theoretical aspects, and also by selecting and analyzing works divulged by Internet literary contests. To fulfill that intent we will mostly use studies by Brazilians Capaverde (2004), Gonzaga (2007), Spalding (2008) and Sanfelice (2009), and also concepts by respected names of the short-story theory as Poe's unity effect, Cortázar's epiphanic openness, Hemingway's iceberg theory and the "a short-story always tells two stories" theory credited to Borges, and developed by Piglia. As a result, we could testify the very existence of excellent specimens of the genre spread

\footnotetext{
${ }^{1}$ Agradecemos, pelas valiosas leituras críticas, à professora Neide Elias da Universidade Federal de São Paulo.

${ }^{2}$ Elizete Rodrigues é professora da rede privada no Estado de São Paulo. Vargem Grande Paulista, São Paulo. Email: morganalia@uol.com.br.

${ }^{3}$ Vanderlei de Souza é professor da FATEC (Faculdade de Tecnologia de Carapicuíba) vinculada ao CPS (Centro Paula Souza) autarquia do Estado de São Paulo. E-mail: vdsgdt @ gmail.com.

${ }^{4}$ Marlene de Almeida Augusto de Souza é professora doutora da Universidade Federal de Sergipe (UFSE). Email:marlenesouza04@yahoo.com.br.

${ }^{5}$ Nossa tradução de trecho da resenha "Tale-writing - Nathaniel Hawthorne", escrita por Edgar Allan Poe em 1847: "Common sense, in the time to come, may possibly insist upon measuring a work of art rather by the object it fulfill, by the impression it makes, than by the time it took to fulfill the object, or by the extent of "sustained effort" which became necessary to produce the impression." Disponível em http://www.eapoe.org/works/criticsm/glb47hn1.htm .
} 
almost anonymous on the Internet, and also that their analysis reaffirms the potential meaning they carry within their tiny body, since we employ an efficient active reading. We conclude that, by its compact nature, and by its great capacity in producing meaning, the genre would be helpful in the field of the critical reading learning. Finally, we recommend that educational research in the field of reading to turn its attention to that almost unexplored lode.

Keywords: Short Stories. Minifiction. Sudden fiction. Literature Theory.

\section{Introdução}

Desde Poe, as narrativas curtas, ou short stories, têm ganhado um espaço de relevância no rol dos gêneros literários mais difundidos e apreciados. Em nossos dias, sob a influência do avanço das novas tecnologias, da rapidez, a miniaturização e da hipertextualidade novas formas de escrita tentam a obtenção do máximo a partir do mínimo. Nesse cenário é que vicejam os contos ultracurtos ${ }^{6}$ disseminados principalmente pela Internet e, alguns dos quais que comporão nosso corpus. Ainda sobre o corpus, optamos por estudar obras divulgadas em resultados de concursos literários na Internet, voltados para o gênero. O potencial de abertura ${ }^{7}$ das narrativas foi o principal critério de escolha utilizado, pois estabelecemos como objetivo primário dessa investigação reconhecer sua capacidade explosiva, ou seja, sua vocação para continuar o enredamento para além da materialidade linguística. Outro objetivo do estudo reside no esforço em valorizar o gênero, apresentando um pouco de sua teoria e uma análise de boas obras não canônicas. Consideramos que o presente estudo se justifica pelo fato de explorar um campo ainda carente de pesquisa acadêmica, mas também pelas possibilidades que abre no âmbito da compreensão leitora, o que traz grande promessa na área de ensinoaprendizagem e multiletramentos.

\section{Um pouco da história dos minicontos}

José Joaquín Blanco (apud STANTON, 1992) afirma que em um país os melhores escritores, antes de investir na criação de uma nova voz, buscam conhecimento em correntes literárias anteriores. Blanco (op. cit.) assevera que nunca haverá uma ruptura com a influência de tais correntes, mas admite a possibilidade de uma renovação poética e também a inovação de procedimentos estéticos. Podemos partir do viés destes estudos hispano-americanos e

\footnotetext{
${ }^{6}$ Zavala (2006) propõe que contos ultracurtos são aqueles que não ultrapassam 200 caracteres.

${ }^{7}$ Conceito que será desenvolvido mais adiante em nosso artigo.
} 
iniciar nossa investigação sobre o fenômeno da minificção ou como denomina Gonzaga (2007), forma mais conhecida deste gênero, o miniconto.

Consideramos pertinente nosso ponto de partida sob a ótica de estudiosos hispânicos por reconhecermos a forte tradição literária que possuem e também, como explica Capaverde (2004, p. 30), por estar entre eles a maior produção do gênero conto. Gonzaga (2007, p. 11) afirma que foi no México que "a minificção floresceu de modo mais luxuriante", principalmente a partir de meados do século XX. Podemos destacar inclusive que entre os hispânicos já existem três gerações de minificcionistas, cujos principais representantes são: Juan José Arreola (1918-2001), Julio Torri (1889-1970) e Augusto Monterroso (1921-2003).

É também entre os hispano-americanos que se desenvolve mais densamente a pesquisa sobre o fenômeno da minificção. Lauro Zavala (apud, GONZAGA, 2007) importante estudioso do gênero (apud Gonzaga, 2007), afirma existir aproximadamente 84 estudos voltados para a minificção em pleno início do século XXI. Somente sobre a famosa obra de Monterroso, intitulada El Dinosaurio, existe uma quantidade razoável de material teórico. Isso sem mencionar a vastidão bibliográfica de Julio Cortázar. Spalding (2008), para elaborar sua tese precisou buscar além da maturidade do gênero entre nossos vizinhos o desenvolvimento do minimalismo nos Estados Unidos, destacando-se a obra de Raymond Carver e o gênero que por lá foi nomeado de flash-fiction. No Brasil já se menciona uma segunda geração de minificcionistas. O Livro Ah, é (1994), de Dalton Trevisan, de acordo com Gonzaga (op. cit.), trata-se de consagrada representação de antologia composta apenas de minificções. Outro representante seria a reunião de microcontos organizados pelo escritor Marcelino Freire, intitulada Os cem menores contos brasileiros (2004).

No que tange à pesquisa, ambas as obras mencionadas serviram de corpus para a análise do gênero da microficção. Outro objeto de estudo foi a composição poética de Oswald de Andrade. E ainda com pioneira abordagem sobre este recente gênero, temos a dissertação de mestrado de Capaverde (2004) com o título: Intersecções possíveis:o miniconto e a série fotográfica. Ainda assim, Gonzaga (2007) e Spalding (2008), consideram haver uma escassez de material teórico sobre a minificção. Eis, portanto, uma das justificativas das quais se serviram aqueles pesquisadores para seu estudo, e que tomamos de empréstimo para o presente artigo.

\subsection{Miniconto: filho do pai}


Continuaremos a explorar nosso referencial teórico sobre o miniconto partindo da premissa estabelecida por Blanco (apud STANTON, 1992, p. 108) que diz que serve de respaldo para novas tendências, o que já existe em correntes literárias anteriores. Neste aspecto, podemos dizer que a nova tendência seria o miniconto e o que lhe antecede o conto propriamente dito. E este serve de ponto de partida para muitos pesquisadores. Gonzaga (2007), por exemplo, adota como índice para medição do miniconto o tamanho dos contos tradicionais e afirma que o miniconto "é oriundo da evolução do conto a partir de Poe" (p. 20). Em nota de rodapé explica:

“A relação do miniconto com os microgêneros clássicos poderá ser de natureza intertextual, mas sua linha evolutiva está muito mais vinculada ao conto tradicional que a outras formas literárias, porque para que haja miniconto é preciso que haja narrativa, narrativa que é herdada da contística que o antecede" (op. cit. p.20).

Em conformidade com o que foi teorizado por Poe (1985) sobre o conto, Sanfelice (2009), o caracteriza da seguinte forma:

"O gênero conto, além de ser uma narrativa curta, deve ser salientado pelo efeito único, que deve causar em seu leitor. A brevidade da narrativa facilita a manutenção de interesse no leitor, apresentando concomitantemente uma unidade e coerências das partes que o compõem. É de importância uma convergência de ações para um conflito, que se desenvolve em uma tensão crescente resolvida no desfecho. $\mathrm{O}$ fato de a narrativa ser curta limita o número de personagens, os recursos espaciais e o tempo dos acontecimentos" (KIEFER, 2004, p. 48 apud SANFELICE, 2009, p.21).

Pela definição de Poe (1985, apud SANFELICE, 2009) já existe no conto clássico ${ }^{8}$ a intenção de que a leitura aconteça em uma assentada só. E para isso faz-se necessário na formulação do conto a busca por mecanismos "minuciosamente calculados", o que ele nomeia como "economia dos meios narrativos". "Nada em um conto deve exagerar ou exceder. O recurso único é trabalhar com profundidade, verticalidade, buscando a expressão do essencial" (POE, 1985 apud SANFELICE, 2009). Fazendo um paralelo a esta visão sobre o conto, Sanfelice (2009) encontra no escritor Charles Kiefer uma precisa relação entre o que propõe Poe (1985), as novas tendências do conto e as vertentes deste:

\footnotetext{
${ }^{8}$ De acordo com Luzia de Maria o conto pode ser classificado, de maneira geral, em clássico, cujos representantes emblemáticos seriam Poe, Maupassant, Quiroga; e moderno, a partir de Tchekhov, passando por Cortázar, Borges e Joyce, Clarice Lispector.
} 
"O novo mundo industrial, o mundo da rapidez das locomotivas, é um mundo construído sobre as bases da linguagem escrita. $\mathrm{O}$ conto moderno não é um causo, para ser decorado e recontado, mas um texto. E um texto não precisa ocupar espaço na memória, ele pode ser reacessado a qualquer instante. Basta abrir o livro e ler, enquanto a paisagem desliza pela janela do vagão. O relativismo da extensão como média ideal para o formato de uma história curta abre a possibilidade para a sua redução na direta proporção do aumento da velocidade, como efetivamente ocorreria na história do conto. Hoje temos as sudden stories, como minicontos, microcontos, etc" (KIEFER, 2004, p. 48 apud SANFELICE, 2009, p. 22).

Para o autor a produção de textos menores, "o relativismo da extensão" está ligado ao tempo. Assim como definiu Gonzaga (2007, p. 33) ser a microficção o "fruto da aceleração de tempos modernos, de um novo contexto de leitura fundado pela fragmentação do próprio tempo dedicado à palavra impressa".

Outro aspecto que advém de estudos não apenas de Poe (1985), mas de Cortázar (2006) e Piglia (2000), que servem para estruturar os conceitos do gênero conto e podem respaldar as composições ultracurtas é a questão da brevidade.

\section{Aspectos do miniconto}

\subsection{A loquacidade do breve}

Poe (1985) em A filosofia da composição estabelece para esta questão dois pontos fundamentais, o psicológico e o estrutural. Quanto ao estrutural, segundo ele, se o conto for muito longo, ficará distante do efeito desejado de intensidade, em outras palavras, conforme Sanfelice (2009, p. 30) "só o breve pode ser intenso" o que vem a ser nas palavras de Poe (1985) "unidade de efeito". Sobre a unidade de efeito, Gonzaga (2007) recorre a Hills (2000), que diz que tudo deve entremear-se de tal forma a tornar-se um único conjunto, e tal resultado somente é obtido com a chamada "perfeita economia". No referido ensaio, Poe (1985) quanto à questão estrutural relacionada à brevidade, diz que "é claro que a brevidade deve estar na razão direta da intensidade do efeito pretendido, e isso com uma condição, a de que certo grau de duração é exigido, absolutamente, para a produção de qualquer efeito" (p. 104).

Da narrativa poética sobre brevidade de Poe (1985) extrairam-se as questões de caráter psicológico, a "unidade de concepção e recepção", como determina Sanfelice (2009). Neste aspecto, estudiosos/escritores latino-americanos como Cortázar (2006) e Quiroga (apud, SANFELICE, 2009) concordam com Poe (1985) acerca da proximidade entre o poema e o conto no que tange à “concepção ou visualização inicial do leitor" em existir uma necessidade 
de ser instantânea. Quanto a isso, o escritor de "O corvo" (1845) afirma que após definir o tamanho de sua composição, o passo seguinte refere-se a escolher "uma impressão ou efeito", para desta forma atingir um apreço por parte de seus leitores. Para tanto, Cortázar (1994, apud SANFELICE, 2009, p. 30), explica que para que o leitor tenha um lapso único, breve e intenso, uma sugestão é que o escritor "abandone qualquer outra atividade até que se tenha cumprida a tarefa de escritura do conto", como, aliás, já sugeria Poe (1985).

Conselhos idealizados à parte, Gonzaga (2007) aponta que é justamente neste aspecto discutido pelos teóricos Poe (1985) e Cortázar (1994) que se ligam a tensão e o ser breve que se narra. E que Imbert (1979, apud GONZAGA, 2007) chama de "primazia da trama". Neste contexto a brevidade é considerada um ponto de partida para outros efeitos, como por exemplo, concisão de personagens, o que não quer dizer que os personagens devam ser triviais ou efêmeros, podendo ser poucos, mas detentores de forte significação, diferentemente dos inúmeros personagens com meras funções complementares no romance. Percebe-se que nestes textos, ocorre uma redução espaço-temporal, ou seja, a supressão de cenário, além de estratégias narrativas.

Sanfelice (2009) nos convida a refletir que muito embora a brevidade esteja relacionada à economia, inclusive dos itens acima citados, a "economia se imbrica à condensação", e incorporada à ideia de condensação serão utilizados no conto estratégias, "truques", como por exemplo o uso de elipses, escolha por momentos dramáticos ou significativos, escolha por cenas-chave, uso do velado, técnicas sintéticas de narração que favorecerão a intensidade culminando ao que se propõe para narrativas curtas, e por quer não dizer mais precisamente aos minicontos?!

\subsection{Um conto, duas histórias.}

De acordo com Gonzaga (2007) a brevidade é o primeiro aspecto relacional que "dentro do miniconto será mais acerbado", o item seguinte que foi estudado como aspecto do conto e que pode vestir a forma do miniconto vem a ser a tese pois "Um conto sempre conta duas histórias." (PIGLIA, 2000) Adotaremos neste artigo, acerca dessa tese, a admissão defendida por Gonzaga (2007) como paradigma Borges-Piglia, pois dessa forma concede a ambos, respectivamente, os créditos pela tese. O próprio Piglia (2000) explica em quais dimensões Borges trabalha com a esta tese, tanto teoricamente quanto na execução de seus contos, em seu livro intitulado Formas Breves: 
"Para Borges la historia 1 es un género y la historia 2 es siempre la misma. Para atenuar o disimular la esencial monotonía de esa historia secreta, Borges recurre a las variantes narrativas que le ofrecen los géneros. Todos los cuentos de Borges están construidos con ese procedimiento" (PIGLIA, 2000, p.110).

Conforme Piglia (op.cit) uma das maiores contribuições dadas pela lucubração de Borges (2007) vem a ser que a história 2 é o tema da história propriamente dita, a principal. Gonzaga (2007) encontra neste aspecto um viés fundamental para se depreender o miniconto, sobretudo no que Piglia (2000) chama de "microscópica máquina narrativa que é o conto", partindo do fazer da escrita para combinar essas duas histórias "a visível e a oculta" dentro de um único conto. Acerca disso, extraímos na própria voz de Piglia (2000) a seguinte explanação, com base no famoso fragmento deixado por Tchekhov ${ }^{9}$ :

El cuento clásico (Poe, Quiroga) narra en primer plano la historia 1(el relato del juego) y construye en secreto la historia 2 (el relato del suicidio). El arte del cuentista consiste en saber cifrar la historia 2 en los intersticios de la historia 1. Un relato visible esconde un relato secreto, narrado de un modo elíptico y fragmentario.

El efecto de sorpresa se produce cuando el final de la historia secreta aparece en la superfície. ( p. 106)

De acordo com Gonzaga (2007), Piglia (2000) passará a tratar o conto moderno (Tchekhov, Mansfield, Joyce), sob a ótica da teoria de Hemingway (apud, SPALDING, 2008), conhecida como teoria do iceberg, tema de nossa próxima investigação.

\subsection{Teoria do iceberg: um gigante oculto}

Conforme Spalding (2008) para o minimalismo teremos como assegurados representantes na literatura, Raymond Carver e Ernest Hemingway. Quanto ao termo minimalismo, Spalding (2008) define da seguinte forma:

“(...) 'minimalismo' remonta a um movimento da pintura e escultura norteamericanas dos anos sessenta, quando artistas como Donald Judd, Dan Flavin e Robert Morris tornaram-se referências ao evitar o excesso de refinamento, evidente em muitas pinturas e esculturas artesanais" (p. 18).

\footnotetext{
9 “Um homem, em Monte Carlo, vai ao cassino, ganha um milhão, volta para casa, se suicida.
} 
De acordo com o pesquisador, encontrou-se nas obras desses escritores uma "redução da narração a signos básicos", o que foi comparada com expressões artísticas típicas da pintura e da escultura que eram encaixadas no movimento minimalista. Hemingway, em explanação sobre sua própria obra, cunhou pioneira teoria, que consiste na ideia de que o que está visível é menos importante do que o que está oculto, conforme Spalding:

"Para Hemingway (apud, SPALDING, 2008) se o livro está escrito com carga suficiente de verdade, deve o escritor omitir partes dessa verdade mesmo sendo interior ao texto: o não-dito prevalece sobre o dito, inaugurando a 'teoria do iceberg"' (p. 19).

E nas próprias palavras de Hemingway ${ }^{10}$ :

"If a writer of prose knows enough about what he is writing about he may omit things that he knows and the reader, if the writer is writing truly enough, will have a feeling of those things as strongly as though the writer had stated them. The dignity of movement of an iceberg is due to only oneeighth of it being above water. A writer who omits things because he does not know them only makes hollow places in his writing. A writer who appreciates the seriousness of writing so little that he is anxious to make people see he is formally educated, cultured, or well-bred, is merely a popinjay" (HEMINGWAY, 1932).

Hemingway (op. cit) ao elaborar genial retórica pretendia fazer uma crítica ao escritor que esconde coisas em seu texto, pelo simples fato de desconhecer tais coisas. O que ele afirma é que se um escritor tem conhecimento preciso do que se propõe a escrever, consequentemente terá recursos para escolher o que quer e o que não quer revelar. E relaciona esse não dito, esse não revelado, com a imensa parte do iceberg que está submersa. "The dignity of movement of an iceberg is due to only one-eighth of it being above water" (op. cit.), ou seja, toda a dignidade do movimento do iceberg ocorre porque apenas $1 / 8$ dele encontra-se acima da água. Em seu famoso miniconto: "Vende-se: sapatinhos de bebê, nunca usados", talvez tenha com êxito conseguido exemplificar o quanto a parte oculta em uma história pode abarcar em profundidade.

\subsection{Epifania e abertura}

\footnotetext{
${ }^{10}$ Disponível em http://www.jamesrament.com/hemingways-iceberg-theory/. Acesso em: 17 de agosto de 2013.
} 
Gonzaga (2007), afirma que é impossível investigar uma produção moderna do conto, ou mais especificamente, a minificção, sem se deter na relação que se "estabelece entre epifania e abertura". De acordo com o estudioso, o que na narrativa tradicional, produzida no final do século XIX vinha a ser a "ação decisiva", ou o clímax de um determinado relato, nas produções modernas ${ }^{11}$ a epifania é que ocupa esse espaço. Quanto ao que vem a ser epifania, o autor afirma que inicialmente a origem da palavra corresponde a "aparecer para" e é reconhecida como termo religioso. Visto assim como algo que surge, que aparece para. De acordo com Gonzaga (2007, p. 23) seria "a partir de Joyce que o termo vai ganhando o sentido literário que possui hoje", quando esse escritor elaborou composições, das quais intitulou de epifanias. E é a partir disso, de acordo David Logde em The art of fiction (1992, apud GONZAGA, 2007, p. 23), que a palavra é usada "para qualquer passagem descritiva na qual a realidade externa é carregada com algum tipo de significado transcendental para o receptor", e é por esse motivo, em que ocorra o uso de um efeito lírico, que a epifania acabará, pois, em promover uma aproximação do texto em prosa do poema.

Conforme Gonzaga (2007), a epifania está ligada à brevidade, ao uso de elipses e metáforas. Para que ela exista é necessário que exista um segredo a ser revelado. Diz ainda que para que haja compreensão dos minicontos "a natureza epifânica será extremamente importante". Uma vez que o leitor se delimite a analisar cenários, tramas e personagens vagos no miniconto, e não siga para a linha epifânica de possibilidades, poderá, pois, perder grande parte da essência do texto.

\subsection{Universo em expansão: abertura}

Conceito criado por Cortázar (1994) ao falar da possibilidade de explosão que determinada obra artística poderia causar no leitor. Para explicar mais detalhadamente no texto Alguns aspectos do conto (online), Cortázar menciona a fotografia de Cartier-Bresson, cuja arte é tida como um "aparente paradoxo":

"La de recortar un fragmento de la realidad, fijándole determinados límites, pero de manera tal que ese recorte actúe como una explosión que abre de par en par una realidad mucho más amplia, como una visión dinámica que trasciende espiritualmente el campo abarcado por la cámara" (CORTÁZAR, online)

\footnotetext{
${ }^{11}$ De acordo com Luzia de Maria (1984) o conto pode ser classificado, de maneira geral, em clássico, cujos representantes emblemáticos seriam Poe, Maupassant, Quiroga; e moderno, a partir de Tchekhov, passando por Cortázar, Borges e Joyce, Clarice Lispector.
} 
Ou seja, a fotografia partindo de uma específica realidade, poderia ocasionar uma explosão que de acordo com a interpretação de Gonzaga (2007, p. 24) desencadearia "uma realidade mais ampla e transcendente" que o retrato inicial. Cortázar (online) diz que o mesmo efeito não se tem de uma obra cinematográfica, tampouco de um romance. Todavia, o contador de história e o fotógrafo são obrigados a selecionar e limitar uma "imagem ou ocorrência que são significativas." (op.cit.) E é a partir disso que ocorre um fenômeno de interação com o leitor, provocando uma espécie de "abertura", de maneira que são estimuladas de maneira mais apurada a sensibilidade e compreensão da obra.

De acordo com Cortázar (1994, apud GONZAGA, 2007), uma das maiores dificuldades do conceito de abertura se deve ao fato deste não dispor de "qualquer prova material que o legitime." Em outras palavras, por se tratar de uma atuação do leitor, poderá sofrer variações de acordo com a individualidade de cada um, como diz Gonzaga (2007), trata-se de uma "questão plenamente interpretativa.", aliás, genialmente utilizado por Cortázar no conto Continuidad de los parques (1964). Partindo deste viés, podemos também colocar o conceito de epifania no mesmo patamar, visto que se trata de uma interação com o leitor. Sobre o imbricamento entre epifania e abertura Gonzaga (2007) ressalta que enquanto a epifania acontece de maneira a iluminar o conteúdo de uma história, trazendo significados sobre essa história com tal revelação, a "abertura é uma expansão universal", não que não se trata também de uma revelação, mas "um uno" que se abre para a visão de um todo. Enquanto a epifania ilumina o que foi lido, a abertura amplia os horizontes para além do texto.

A seguir procederemos à análise dos seis contos que compõem o corpus deste estudo levando em consideração os conceitos acima discutidos.

\section{Análise de minicontos divulgados por concursos literários na Internet}

Uma vez discutidos os conceitos básicos que envolvem o miniconto analisaremos o corpus com a finalidade de explorarmos suas possibilidades interpretativas, sua abertura, além demonstrarmos a presença de uma característica importante nos contos clássicos e modernos que ainda pode ser reconhecida nos seus parentes extremamente curtos que proliferam na Internet em nossos dias. Trata-se da economia de recursos para a obtenção do máximo de efeito sobre o leitor. Para isso selecionamos um corpus composto de minicontos que 
participaram de concursos literários voltados para o gênero, disponíveis na rede mundial de computadores.

\section{Miniconto 1 - O ÚLTIMO A SABER ${ }^{12}$ (Márcio Fernando Silveira)}

Parecia ser a sua sina eterna. Novamente foi o último a saber. Ao entrar perambulando no bar onde alguns entristecidos amigos saciavam a sede, soltou um grito ao perceber que só faltava a sua sombra na parede.

Quando se trata de conto tudo que for acessório deve ser suprimido em favor do efeito que se quer produzir no leitor. Assim, este não é mero expectador diante da narrativa e sim parte ativa no processo. $\mathrm{O}$ autor do texto acima não precisou nomear ou descrever seus personagens, nem detalhar seu cenário para nos sugerir uma história completa utilizando algumas poucas frases. O protagonista, um adulto do gênero masculino, morreu e a forma pela qual descobrimos o fato é engenhosamente construída sem que se diga isso de forma direta. Há pouca chance de seus amigos estarem "matando a sede" com algum líquido que não fosse alguma bebida alcoólica. Sucessivas inferências serão construídas para que seja montado o contexto da história.

Como diria Poe (1985), todo o enredamento deve servir ao único propósito de causar no leitor algum tipo de efeito. Nesse caso, o efeito é a surpresa em descobrir que o personagem já não se encontra entre os que respiram ou têm sombra. Mais do que isso, somos alertados desde o princípio que o personagem principal já fora vítima de algum tipo de situação em que ignorava acontecimentos sobre a própria vida. As frases "parecia ser a sua sina eterna" e "novamente foi o último a saber" revelam a recorrência desse infortúnio. Resta-nos especular sobre que desinformações seriam essas e se isso tem algo a ver com sua morte. Normalmente associamos o sintagma "o último a saber" com traição conjugal, em virtude da associação com o provérbio popular "O marido é sempre o último a saber". Por conseguinte pode nos vir à mente um suposto assassinato que teria sido engendrado pela esposa e seu amante.

12 Disponível em: http://autoressaconcursosliterarios.blogspot.com.br/2013/05/os-20-minicontosclassificados.html. Acesso em 17 de agosto de 2013. 
Embora poucos recursos tenham sido mobilizados para garantir um grande potencial de significação, pelo menos uma falha pode ser detectada nessa tentativa de enxugamento formal. A frase "novamente foi o último a saber" ficou redundante, uma vez que a frase anterior já garante a repetição do fato e o título sua associação com traição conjugal. Uma saída seria a utilização de um elemento chave que já faz parte da composição do conto, em que o enxugamento formal acaba sendo impreterível para o efeito atômico ${ }^{13}$.

\section{Miniconto 2 - O ESCONDERIJO ${ }^{14}$ (Rejane Gonçalves dos Santos)}

Gostava muito de brincar de esconde-esconde com minha mãe. Um dia, ela se escondeu dentro de uma caixa de madeira escura, cobriu-se de flores e não quis mais sair.

Se o miniconto 1 em conformidade com nossa leitura trata sobre a morte a partir de uma abordagem fantástica, temos em "O esconderijo" uma tentativa bem sucedida em privilegiar a sensibilidade e a delicadeza ao traduzir um momento triste também sob a forma de metáforas.

Novamente, a forma indireta de dar ciência dos fatos ao leitor predomina, entretanto, desta vez, não é mais a intenção de causar surpresa ao leitor que explica essa implicitude. Se há um efeito a ser impresso no interlocutor deste texto, passa pela capacidade humana de se emocionar com a beleza lúgubre do acontecimento mais comum e mais trágico da existência.

Ao tentarmos reconstruir a história de mãe e filha (ou filho?) teremos pouca chance de não imaginá-la de forma idealizada em que o amor entre eles já não seja o cimento que os une de forma inequívoca e inquebrantável. Isso porque a delicada escolha lexical é uns dos artifícios da materialidade linguística utilizados pela autora que nos impele a buscar caminhos interpretativos distantes de quaisquer acontecimentos dolorosos que possam ter havido entre os personagens.

Apesar disso, de acordo com nossa interpretação, não significa que a mãe tenha logrado uma felicidade inconteste. Se por um lado usufrui do amor materno/filial, um fio de melancolia escorre em seu rosto e pode ser percebido na sequência final: "ela se escondeu dentro de uma caixa de madeira escura, cobriu-se de flores e não quis mais sair”. A escolha da

\footnotetext{
${ }^{13}$ Usamos aqui a expressão "efeito atômico" para fazer um paralelo metafórico entre o miniconto e a bomba atômica por compartilharem características de concentração e explosividade.

${ }^{14}$ https://www.facebook.com/permalink.php?story_fbid=478984502122235\&id=401857246501628
} 
voz reflexiva por parte da autora desvela dois atos exercidos de si para si e uma resolução derradeira, a de não querer mais sair. Sugere-se, não um arrebatamento de seu sopro de vida por força externa, mas uma decisão voluntária: suicídio? Ao buscarmos uma razão para esse ato extremo trilharíamos outros caminhos de um enredo que só existiria em nossa nova condição de leitor que escreve a história tanto quanto ou mais que o próprio autor.

\section{Miniconto 3 - LAÇOS DE FAMÍLIA ${ }^{15}$ (Edweine Loureiro da Silva)}

Enquanto terminava de fazer o nó na gravata do pai septuagenário, veio-lhe ${ }^{16}$ à memória todos os abusos sexuais que sofrera dele quando criança. E foi assim que, naquela manhã, decidiu fazer-lhe o nó um pouco mais forte...

Mais uma vez nos deparamos com o tema da morte e da família, agora numa conjunção menos simbiótica que no conto anterior. Ao invés das metáforas singelas de "O esconderijo" Edweine Loureiro recorre a finas ironias que dialogam com a brutalidade dos eventos pintados sem nenhum floreio em sua narrativa.

A dupla articulação passado/presente e infância/velhice são as chaves para entender a proposição desse miniconto, pois é a partir dela que a inversão dos papéis torna-se evidente. A vítima agora é o algoz, o fraco agora é o forte e a vingança é inexorável. Há dois laços que são causa e consequência no desenrolar da trama, o primeiro é o de família, aquele que idealmente deveria servir de vínculo saudável de união de entes que se querem bem e que deveriam se proteger, mas que ironicamente revela-se brutal, vil. O segundo laço é o da gravata, peça de vestuário que não se usa cotidianamente, mas em ocasiões especiais. Que ocasião seria essa? O casamento do personagem? Mais uma vez a ideia de enlace salta aos olhos.

O leitor tem a responsabilidade de preencher as lacunas dessa tessitura observando as pistas deixadas. Por que a vingança demorou tanto? Por que não há qualquer ação por parte do pai no tempo presente? Com o passar do tempo houve perdão entre os dois? Se não, por 
que estaria o personagem principal cuidando de seu pai sem que este suspeitasse de qualquer possibilidade de agressão?

Todas essas perguntas podem nos conduzir a outra possibilidade de continuidade narrativa para além da materialidade discursiva. Não, não houve vingança. Sim o pai está morto, mas não vitimado pela suposta esganadura da filha(o). Morreu por alguma moléstia agravada pela idade avançada. Cabe ao personagem vesti-lo, prepará-lo para o enterro. Em seu interior uma confusão de sentimentos entre a tristeza de perder o pai já perdoado por ela(e) e a mágoa ainda ressentida que a(o) impele a apertar a gravata mais fortemente numa tentativa vã e tardia de vingança

\section{Miniconto 4 - UM A ${ }^{17}$ (Wellington Júnio Costa)}

Lá, onde vivia, a criança só queria um presente de natal: poder usar uma letra a mais no seu nome. Não deixaram. Cresceu sem dizer um a, foi morar na capital, assumiu o desejo, cortou a palavra que sobrava no corpo e assinou Daniela.

Em um sensível jogo de adição e subtração o autor nos permite participar do universo de uma criança que sempre soube o que queria quanto a sua identidade neste mundo engessado. "Lá, onde vivia" nos remete ao conservadorismo das pequenas cidades interioranas em que sua condição transexual teria pouca chance de vingar. É nesse espaço social que lhe foi negada sua cidadania mais íntima, isto é, o direito de ser o que é. Imaginamos as inúmeras formas de silenciamento de suas verdades e o sentimento de não pertencer ao modelo familiar, escolar, legal e religioso. Nem mesmo Papai Noel aprovava a escolha de seu presente de Natal.

Enquanto esteve sob a tutela da família foi obrigado a reprimir sua verdadeira condição, no entanto sua resignação "Cresceu sem dizer um a”, é apenas temporária, convicto que sempre esteve de sua futura luta. Em oposição, "foi morar na capital", seja ela qual for, nos conduz à ampliação de horizontes, à aceitabilidade de novos paradigmas, à convivência com as diferenças, à descoberta de iguais e à consequente possibilidade de resgate da própria dignidade. 
A própria condição legal parece ter sido alterada, pois o termo "assinar" sugere não apenas uma assunção pessoal de sua nova identidade, mas também um "consentimento" social, fruto das novas prerrogativas conquistadas no âmbito das leis. Não há como não reverenciar a perspicácia literária do autor que, longe de malabarismos linguísticos, impõe sua inteligência escritora de forma sutil e contida que, contudo, redunda em rios narrativos incontroláveis.

Especial atenção para os jogos com a letra "a". Já no título temos uma genial sugestão: "Um a". Afinal o personagem é "um" homem ou é "a" mulher? Junte-se as duas palavras e teremos a resposta: "Uma". Eis a revelação de uma estratégia poderosa de reunião de elementos o que desencadeia no efeito de epifania e de abertura. Em português o "a" é um morfema gramatical indicativo de gênero feminino. Assim, "ele" é um "a" e não um "o", morfema gramatical indicativo de gênero masculino. Não poder dizer um "a", além de sua função mais óbvia de silenciamento, como expressões "não dizer nem mais um pio", pode ainda significar que a "ele" é sim, permitido dizer, desde que diga "o" e não "a", ou seja, desde que assuma a identidade à pessoa impingida e não a que ele sente ser a sua verdadeira.

Não sabemos se consciente ou inconsciente, mas o fato é que ao flagrar o personagem no momento em que assina seu novo nome, símbolo de uma vitória, o autor reitera graficamente a transformação final de sua criatura: DaniELA.

\section{Miniconto 5 - Falosofia ${ }^{18}$ (Renato Conterato)}

Após o ato, ela:

- A felicidade está nas pequenas coisas.

Ele olhou para baixo. Cobriu-o com a mão. Tristeza. Esta sim: imensa

Como ficou patente nas análises anteriores a leitura ativa é crucial para que a narratividade flua, mesmo assim é condição necessária, mas não suficiente, pois é no plano da materialidade linguística que este leitor ativo buscará pistas para conjugar os elementos básicos da narrativa, é aí que entra a maestria do escritor. Vejamos como esses elementos são combinados no conto Falosofia.

\footnotetext{
${ }^{18}$ Disponível em: https://docs.google.com/file/d/0B1aQPxR3vjHgXzNSaVFFQXZyRmc/edit. Acesso em 17 de agosto de 2013.
} 
Quanto à ação, constatamos que se trata de um epílogo, momento que se segue ao clímax. Primariamente é solicitado ao leitor que enquadre essa ação em algum tipo de modelo de seu repertório pessoal. Nesse caso é necessário que este tenha vivências e informações no campo da sexualidade humana, para que perceba qual é a situação e o que está em jogo. Feito isso, temos um homem e uma mulher, provavelmente ${ }^{19}$ em um quarto, lado a lado na cama, após um ato sexual.

O vínculo entre eles não é revelado, o que possibilita a abertura de várias frentes de construção do enredo que antecede ao flagrante captado no miniconto. Temos um comentário por parte da mulher que pode, ao mesmo tempo, mostrar sua satisfação ou exatamente o contrário, uma vez que a reação do homem parece ratificar a segunda hipótese.

Por fim, cabe, dessa maneira, perfeitamente o título empregado já que o pós-coito abre espaço à reflexão fi/falosófica que sobrevêm: “- A felicidade está nas pequenas coisas.”. Esse comentário cifrado deslinda-se a partir do sintagma "pequenas coisas" e de sua interação com o título do conto "Falosofia". A declaração da personagem é colocada de forma a construir um todo plurissignificativo. Fosse a cena apresentada em forma de vídeo ou áudio teríamos mais elementos para averiguar se trata-se de tom irônico ou não.

Felizmente, o gênero conto, e muito mais ainda o miniconto, exige de nós uma postura investigatória diante dos mais simples objetos significantes em seus mais recônditos detalhes, o que culmina, quando de uma bem sucedida leitura, no prazer da descoberta.

Não é possível afirmar, em um primeiro momento, se a personagem está realmente satisfeita com o ato sexual que se findou ou se procura humilhar o parceiro, incapaz de proporcionar-lhe "felicidade". Embora a sequência marcada pelo comportamento contrariado do parceiro aponte para um decepcionante fracasso em que procura esconder sua (aparentemente) insuficiente magnitude.

Há pelo menos outra possibilidade não menos autorizada para seu acabrunhamento.

Pensemos, pois, em um cenário menos agressivo. A mulher tem uma boa convivência com seu parceiro, sente-se conscientemente tranquila com relação à qualidade do relacionamento sexual e afetivo, mas comete um ato falho ao tentar dizer que são pequenas coisas, como uma boa relação sexual, que podem proporcionar momentos de felicidade. Em

\footnotetext{
${ }^{19}$ Obviamente, essa é apenas uma possibilidade interpretativa, o leitor ativo conduzirá a narrativa a partir de suas vivências, desejos, fantasias e capacidade criadora.
} 
seu íntimo (inconsciente?), vítima que é dos discursos veiculados socialmente, principalmente pela mídia, ratifica a ideia de que tamanho é documento.

No parceiro, não importa se uma ou outra interpretação, o resultado é sempre devastador, pois mesmo que haja aprovação por parte da companheira, qualquer alusão a uma possível diminuição de sua virilidade, vítima que é em maior grau ainda dos mesmos discursos veiculados socialmente, torna-o inferiorizado em sua condição de macho da espécie. Para terminar, é a antítese, a figura que melhor caracteriza o sentimento do personagem: pequenas coisas versus tristeza imensa.

\section{Miniconto 6 - Geladeira ${ }^{20}$ (Amanda D'Andrea Löwenhaupt) ${ }^{21}$}

Fechou a porta da geladeira e virou as costas. Não, definitivamente não queria saber o que uma lontra viva estava fazendo ali.

\section{Miniconto $7^{22}$ - (Mara Augusta Soares)}

Ao pular na garganta do penhasco, ele sonhou.

Quando Monterroso trouxe ao mundo "El Dinosaurio" ${ }^{23}$ talvez não divisasse o impacto que seu miniconto causaria nas gerações seguintes. Ainda que a intenção inicial do autor fosse a de caricaturar a situação política mexicana de sua época, acabou por erigir um monumento que se tornou um marco na história das narrativas ultracurtas.

Seu relato unifrásico tem alimentado a imaginação de muita gente que viu nas lacunas deixadas pelo mestre espaço suficiente para uma escritura leitora ${ }^{24}$. A "Geladeira" de Löwenhaupt e "Ao pular na garganta do penhasco, ele sonhou" guardam certa semelhança com o famoso conto do escritor hondurenho.

\footnotetext{
20 Disponível em: https://docs.google.com/file/d/0B1aQPxR3vjHgXzNSaVFFQXZyRmc/edit. Acesso em 17 de agosto de 2013.

${ }^{21}$ Os contos 6 e 7 serão analisados conjuntamente pela similaridade de alguns critérios que utilizamos para suas interpretações.

22 Disponível em: http://autoressaconcursosliterarios.blogspot.com.br/2013/05/os-20-minicontosclassificados.html. Acesso em: 17 de agosto de 2013.

${ }^{23}$ Segue na íntegra: "Cuando despertó, el dinosaurio todavía estaba allí".

${ }^{24}$ Usamos a expressão aqui para nomear o ato de dar continuidade ou anterioridade a uma narrativa preponderantemente elíptica.
} 
No primeiro miniconto sente-se no ar um certo clima, senão fantástico, estranho. Tal qual o dinossauro que simplesmente se materializa diante de um recém-desperto personagem, vindo das profundezas da Era Jurássica, uma lontra encontra-se instalada na geladeira do protagonista de Löwenhaupt sem maiores explicações. A história que redundou na aparição daquele animal no local mencionado parece ser menos importante que o motivo pelo qual o personagem resolve ignorá-lo. Nesse ponto a autora utiliza de uma técnica oposta à de Monterroso. Se este instiga o leitor a criar uma anterioridade que justifique a presença do grande réptil e uma continuidade que caminhe para o desfecho da incômoda situação, aquela demove o leitor da tarefa de preencher as lacunas.

Apesar disso, sempre podemos interpretar a falta de interesse do personagem como uma pista para uma nova linha de ação narrativa, como por exemplo, a constatação de algum estado alterado de consciência por que passa no momento do clímax.

Já no segundo conto temos uma coincidência na estrutura física deste com "E1 Dinossaurio". Ambos são unifrásicos, bi-oracionais e utilizam-se de subordinadas adverbiais. Em comum, ainda em termos de materialidade linguística os dois textos compactam radicalmente seus recursos narrativos. Porém, a supressão do pronome pessoal "ele", na segunda oração do conto do penhasco, não causaria prejuízo em termos semânticos e contribuiria com o alargamento das possibilidades interpretativas no melhor estilo "Menos é mais".

Cada uma das duas orações remete a uma dimensão diferente da holística humana, de um lado a crueza realista do salto para a morte em toda sua plenitude física, agressiva, dura, inóspita e de outro, a possibilidade do devaneio introspectivo, manso, volátil, imaterial; mundos que se tocam em um portal chamado ser humano. Novamente, as possibilidades de construção de uma anterioridade ao clímax viabilizam-se a partir de especulações sobre o que teria conduzido o personagem àquela ação extrema. De novo, o caráter elíptico desse conto o aproxima da extraordinária narrativa de Monterroso.

\section{Considerações finais}

Iniciamos a presente jornada investigativa com o desejo de valorizar os minicontos, tanto apresentando um pouco de sua teoria, como demonstrando o quanto se pode "extrair" de tão exígua matéria-prima. Findo o processo sentimos a necessidade de reafirmar a necessidade de conhecermos melhor esse gênero narrativo via investigação científica ou mesmo pela sua 
leitura por prazer. Essas narrativas, quando bem elaboradas, possuem um poder "atômico" que é detonado pela leitura crítica, atenta, eficiente. Nesse sentido, vislumbramos sua forte vocação para o uso em sala de aula e em livros didáticos como ferramenta para o ensinoaprendizagem de leitura e, em menor medida, de escrita. Recomendamos, portanto, que a pesquisa acadêmica volte seu olhar para este potencial. Consideramos não menos importante o fato de encontrarmos bons textos de autores fora do cânone, o que pode insinuar que a Internet, apesar das promessas, ainda precisa de iniciativas externas para servir de meio para a valorização de obras fora do mainstream.

\section{Referências}

ARAÚJO. R. Edgar Allan Poe. Um homem em sua sombra. Cotia: Ateliê Editorial, 2002.

ALVES, F. A. do N. Ventanas a lo insólito: A fotografia em contos e ensaios de Julio Cortázar. Itinerários, Araraquara, n.33, p.189-210, July/Dec., 2011. Disponível em: http://www.google.com.br/url?sa=t\&rct=j\&q=\&esrc=s\&source=web\&cd=2\&ved=0CC0QFjA B\&url=http\%3A\%2F\%2Fseer.fclar.unesp.br\%2Fitinerarios\%2Farticle\%2Fdownload\%2F486 8\%2F4095\&ei=xI1QUM2pNYn-

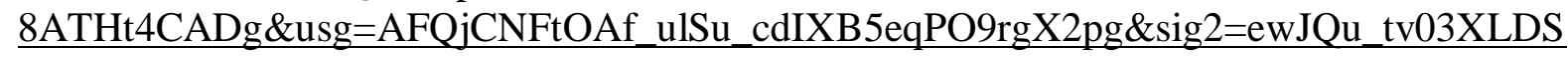
4ACeny1A. Acessado em: 08 set. 2012.

BRASCA, R. La elocuencia del silencio. Sobre el final de la microficiones. Cuadernos del Cilha. Argentina, $\quad$ n.13, 2010. 2 Disponível em http://www.scielo.org.ar/pdf/ccilha/v11n2/V11n2a03.pdf. Acesso em: 20 ago. 2012.

EAGLETON. T. Teoria da Literatura. Uma Introdução. Tradução de Waltensir Dutra. São Paulo: Martins Fontes, 2001.

CAPAVERDE. S. T. Intersecções Possíveis: O miniconto e a série fotográfica. Dissertação (Mestrado em Literatura) - Instituto de Letras, Universidade Federal do Rio Grande do Sul, Rio Grande do Sul, 2004.

CIUDAD SEVA. Continuidad de los parques. Disponível em http://www.ciudadseva.com/textos/cuentos/esp/cortazar/continui.htm. Acessado em: 05 out. 2012

COLETÂNEA MICROCONTOS DE HUMOR 2012.doc. Disponível em:(https://docs.google.com/file/d/OB1aQPxR3vjHgXzNSaVFFQXZyRmc/edit). Acessado em: 12 set. 2012

FIX100. Revista hispanoamericana de ficción breve. N.1, Peru, Julio-diciembre de 2009. Disponível

em: http://www.cpecperu.org/docs/cpec/pdf/Fix 100\%20numero\%201\%20\%281.21\%20MB\%29.p df. Acessado em: 29 ago. 2012

GONZAGA. P. A poética das minificções: Dalton Trevisan e as ministórias de Ah, é? Dissertação (Mestrado em Literatura) - Universidade Federal do Rio Grande do Sul, Porto Alegre, 2007. 
KOCK, D. Retorno al micro-relato: algunas consideraciones. En El Cuento en Red, n.1, primavera 29-31. Disponível em: http://www.xoc.uam.mx/. Acessado em: 28 ago. 2012

LAGMANOVICK, D. Oh, le mot juste!Precisiones antipáticas (pero útiles) sobre el microrrelato. Revista hispanoamericana de Ficción Breve. Peru, n. 1, Julio-diciembre de 2009. Disponível em: http://pt.scribd.com/doc/86266012/Fix100-numero-1-1-21-MB. Acessado em: 28 ago. 2012.

LUZIA, Luzia de. O que é conto. Coleção primeiros passos 135. São Paulo, Editora Brasiliense, 1984.

PIGLIA. R. Formas Breves. Buenos Aires: Anagrama, 2000.

POE. A. E. Poemas e Ensaios. Tradução de Oscar Mendes e Milton Amado. Rio de janeiro: Globo, 1985.

RESULTADO DO CONCURSO NACIONAL DE MINICONTOS. Disponível em: https://www.facebook.com/permalink.php?story fbid=478984502122235\&id=401857246501628.

Acessado em: 17 de agosto de 2013.

ROMERO. R. Epifanía y poema em prosa (El libro do desassossego de Fernando Pessoa/Bernardo Soares). Forma Breve. N.2, 2004, p. 71, 80. Disponível em: http://www2.dlc.ua.pt/classicos/formabreve02.pdf. Acessado em: 07 set. 2012.

SANFELICI. A. Narrativas curtas dos anos 90: suturas/fissuras. Tese (Doutorado em Literatura) Instituto de Letras, Universidade federal do Rio Grande do Sul, Porto Alegre, 2009.

II CONCURSO TODOPROSA DE MICROCONTOS PARA TWITTER. Disponível em: http://veja.abril.com.br/blog/todoprosa/interatividade-2/ii-concurso-de-microcontos-mais-21motivos-para-que-venha-o-terceiro/. Acessado em: 12 set. 2012

SPALDING. M. Os cem menores contos brasileiros do século e a reinvenção do miniconto na literatura brasileira contemporânea. Dissertação (Mestrado em Literatura)- Instituto de Letras, Universidade federal do Rio Grande do Sul, Porto Alegre, 2008.

STANTON, A. Lo culto y lo coloquial en la poesía mexicana contemporánea. Cuadernos Hispanoamericanos. Madrid, 1991, n. 501, p. $101-$ 112. Disponível em: http://dialnet.unirioja.es/servlet/articulo?codigo=161869. Acessado em: 25 ago. 2012. 